\title{
Attempts to commit suicide by exogenous intoxication with medication in a city of the southeast region of Brazil
}

\author{
Tentativas de suicídio através de intoxicação por medicamentos em uma cidade do sudeste do \\ Brasil
}

Intentos de suicidio por intoxicación por drogas en una ciudad del sureste de Brasil

\author{
Ana Lúcia Ferreira Ratão \\ ORCID: https://orcid.org/0000-0002-3471-5915 \\ Municipal Health Network of Birigui, Brazil \\ E-mail: analuciaratao@gmail.com \\ Leandro Figueiredo dos Santos \\ ORCID: https://orcid.org/0000-0002-2908-9286 \\ Universidade Paulista, Brazil \\ E-mail: profleandrofs@gmail.com \\ Ana Cláudia Soncini Sanches \\ ORCID: https://orcid.org/0000-0003-2828-6701 \\ Universidade Paulista, Brazil \\ E-mail: ana.sanches@docente.unip.br \\ Laura Emilia Michelin Gobbo \\ ORCID: https://orcid.org/0000-0002-7172-372X \\ Centro universitário São Camilo, Brazil \\ E-mail: laauramichelin@gmail.com \\ Edelcio Ratão \\ ORCID: https://orcid.org/0000-0002-0859-913X \\ Centro Paula Souza de Birigui, Brazil \\ E-mail: edelcioratao21@gmail.com \\ Aparecida de Fatima Michelin \\ ORCID: https://orcid.org/0000-0001-9162-5935 \\ Universidade Paulista, Brazi \\ E-mail: aparecida.michelin@docente.unip.br
}

\begin{abstract}
Introduction: Exogenous intoxication (EI) is the second most commonly used method to commit suicide, preceded by hanging, and is the first in terms of suicide attempts. Objective: To analyze suicide attempts to EI prevalence and the factors associated with this practice in the population of of the municipality of Birigui/SP. Methods: This is a descriptive, retrospective and observational study of the population of the municipality of Birigui. Data obtained by extracting information contained in the database of the Department of Informatics of the Unified Health System (DATASUS ) of the Brazilian Ministry of Health. Using the TabNet Win32 3.0 program, we analyzed data for the period 2013 - 2017, focusing on six variables: race, sex, education, age group, clinical evolution, and type of exposure. Results and conclusions: 296 cases were studied, increase in suicide attempts by EI through medication over the years from 27 cases 2014, culminating in 108 cases in 2017. Most cases were with females in all years ( $n=35$ in 2013, $n=27$ in 2014, $n=35$ in 2015, $n=51$ in 2016 and $n=84$ in 2017), The highest incidence was found in the 15-19 years population $(\mathrm{n}=49)$ with low education. Acute, single exposure intoxication predominated over others with $53 \%$ of cases $(n=157)$ and cure without sequelae was observed in $63.9 \%$ of cases $(n=189)$. During this period, there was an increase in suicide attempts due to EI over the years predominantly young women and persons of a low level of education.
\end{abstract}

Keywords: Drugs; Exogenous intoxication; Suicide attempt.

\section{Resumo}

Introdução: A intoxicação exógena (IE) é o segundo principal meio de mortes por suicídio, precedida do enforcamento, e a primeira no que se refere às tentativas. Objetivo: Traçar a prevalência de tentativas de suicídio por IE e os fatores associados a essa prática na população do município de Birigui/SP. Métodos: Este é um estudo descritivo, retrospectivo e observacional, realizado no município de Birigui/SP. Foram analisados dados referentes às tentativas de suicídios por IE, no período de 2013-2017, do Departamento de Informática do Sistema Único de Saúde (DATASUS), do Ministério da Saúde do Brasil. Por meio do programa TabNet Win32 3.0, analisou-se seis variáveis: raça, sexo, escolaridade, faixa etária, evolução clínica e tipo de exposição. Resultados e conclusões: Foram estudados 
296 casos, sendo observado um aumento no número anual a partir de 2014 ( 27 casos), culminando em 108 casos em 2017. A maioria dos casos foi com pessoas do sexo feminino em todos os anos ( $n=35$ em 2013, $n=27$ em 2014 , $n=35$ em 2015, n=51 em 2016 e n=84 em 2017), com maior incidência na população de 15-19 anos (n=49) e de baixa escolaridade. A exposição aguda-única predominou sobre as outras com 53\% dos casos $(\mathrm{n}=157)$ e a cura sem sequela foi observada em $63,9 \%$ dos casos $(n=189)$. Nesse período, houve aumento das tentativas de suicídio por IE por medicamentos ao longo dos anos, principalmente em pessoas jovens do sexo feminino e com menor nível de escolaridade.

Palavras-chave: Intoxicação exógena; Medicamentos; Tentativa de suicídio.

\section{Resumen}

Introducción: La intoxicación exógena (IE) es el segundo principal medio de muerte por suicidio, precedido del ahorcamiento, y el primero en términos de intentos. Objetivo: Analizar la prevalencia de intentos de suicidio por IE y los factores asociados en la población de la ciudad de Birigui / SP. Métodos: Se trata de un estudio descriptivo, retrospectivo y observacional, realizado en la ciudad de Birigui / SP. Se analizaron los datos de intentos de suicidio por IE, en el período 2013-2017, del Departamento de Informática del Sistema Único de Salud (DATASUS), del Ministerio de Salud de Brasil. A través del programa TabNet Win32 3.0 considerando seis variables: raza, sexo, educación, edad, curso clínico y tipo de exposición. Resultados y conclusiones: Se estudiaron 296 casos, con un aumento en el número anual desde 2014 (27 casos), culminando en 108 casos en 2017. La mayoría fueron mujeres en todos los años $(n=35$ en 2013, $n=27$ en 2014, $n=35$ en 2015, n = 51 en 2016 y n = 84 en 2017), con mayor incidencia en la población de 15 a 19 años $(n=49)$ y con bajo nivel educativo. La exposición aguda única predominó sobre otras con el 53\% $(n=157)$ y se observó curación sin secuelas en el 63,9\% de los casos $(n=189)$. Durante este período, hubo un aumento de los intentos, especialmente en mujeres jóvenes y con menos educación.

Palabras clave: Intento de suicídio; Intoxicación exógena; Medicamentos.

\section{Introduction}

Suicide is a global problem, with more than 800,000 people ending their lives every year in the world, which corresponds to more deaths than from breast cancer or war (WHO, 2019). This public issue is among the main causes of death in individuals aged 15 to 35 years, with approximately $79 \%$ of cases occurring in low-and middle-income countries. (WHO, 2019). Brazil's suicide mortality rate increased by approximately 16\% between 2007 and 2016, totaling 106,374 deaths, corresponding to 5.8 deaths per 100 thousand inhabitants in 2016 (Brasil, 2017).

Among the main methods used to commit suicide, exogenous intoxication is the second most common, while death by hanging is the first (Brasil, 2017). It is estimated that suicidal attempts outnumber the number of suicides by at least 10 times and that, in general, men choose violent methods such as hanging and firearms, while women use exogenous intoxication (Trevisan; Santos \& Oliveira, 2012).

From 2007 to 2016, of the 470,913 cases of exogenous intoxication, 46.7\% were due to attempted suicide, with women representing about $70 \%$ of cases; the most commonly used toxic agents were medicines (BRASIL, 2018). In addition to medicines, poisonous plants and agricultural pesticides were also used (Rodrigues et al, 2009). In 2017, there was a five-fold increase in notifications of suicide due to exogenous intoxication, especially in the southeastern region of Brazil, which constitutes $49 \%$ of notification of the all Brasil (Brasil, 2018).

The ability to kill oneself results from an interaction of biological, genetic, psychological, sociological, cultural, and environmental factors; it is estimated that $90 \%$ of the individuals who committed suicide had some mental disorder; depression represents $60 \%$ of this disorder (OMS, 2006). It is very important to understand the reasons for suicidal tendencies in order to focus on prevention consisting of family counseling, treatment of mental disorders, community education, referral to psychiatric treatment centers, therapeutic monitoring, and treatment of alcohol and narcotics consumption (OMS, 2006).

Following the World Health Organization (WHO) goal of reducing suicide, the Health Ministry of Brazil is adopting several measures such as emphasis on the training of professionals, the expansion of the mental health care network in the areas of greatest risk, and the creation of a national plan of suicide prevention, and other preventive actions (Brasil, 2017). 
In Brazil, suicidal attempts due to self-intoxication that occurred in the period between 2007 and 2017 resulted in 12,000 hospitalizations costing an average of R\$ 3 million/year, equivalent to the implementation of eight Psychosocial Care Centers (CAPS) that have been proven to reduce suicide risk; this reveals the economic relevance of investment in preventive steps (Brasil, 2018).

Suicide is a public problem that requires money to be spent on preventive actions, and exogenous drug intoxication represents a frequent choice of suicidal attempts, especially in the Southeast region of Brazil. Therefore, this work aims to trace the prevalence of suicide attempts by exogenous intoxication with drugs, and the factors and profiles of people associated with this practice in the population of Birigui city in São Paulo state of Brazil.

\section{Methodology}

This was a descriptive, retrospective, and observational study, with a quantitative approach. Such a mathematical focus is important because it makes it possible to predict related events (Pereira, et al. 2018). The study sample was limited to the population of Birigui City located in the northwest region of São Paulo (SP), a state in the southeast region of brazil. The population of Birigui City in 2010 was 108,728 inhabitants, $16.33 \%$ under 15 years old, and $16.46 \%$ over 60 years old; therefore, the majority of the population was between 16 and 59 years old (IBGE, 2010). This is an industrial city mainly in the urban area; the industry formally employed $42.84 \%$ of the population in 2018 (SEADE, 2020).

The data of number of suicidal attempts in the city by exogenous drug intoxication between 2013 and 2017 were extracted from the Health Ministry of Brazil Informatics Department of the Unified Health System database (Departamento de Informática do Sistema Único de Saúde, DATASUS) using the TabNet Win32 3.0 program. The database is populated through compulsory notification forms on exogenous intoxications filled in public and private emergency units that are sent to the Municipal Epidemiological Surveillance for registration in the Information System of Notifiable Diseases (Sistema de Informação de Agravos de Notificação, SINAN). It is noteworthy that 2017 was the last year in which the DATASUS database recorded notifications of suicidal attempts; there are no data available in this system for the period between 2018 and 2020.

Six variables were analyzed: race, sex, education, age range (10-14 years, 15-19 years, 20-39 years, 40-59 years, 60-64 years, and 70-79 years), the evolution of the clinical condition (ignored, cure with sequel and cure without sequel), and type of exposure (ignored, single acute, repeated acute [more than one exposure in less than 15 days], and chronic [exposure above 15 days]).

Data analysis was performed using Microsoft Excel 2020, and the study variables were presented using descriptive statistics showing the relative (lrb\%) and absolute (n) distribution of the data and presented in the form of graphs and tables.

\section{Results and Discussion}

From 2013 to 2017, 296 cases of attempted suicide due to exogenous drug intoxication were reported in the city of Birigui. The total number of suicide attempts stabilized in $2013(\mathrm{n}=40)$ and the subsequent year $(\mathrm{n}=37)$, and increased in the following years to 49 cases in 2015, 69 in 2016, and 108 in 2017. There was a predominance of female notifications throughout the study period, with the proportion of one man for every three women, represented by $87.5 \%, 72.9 \%, 71.4 \%$, $73 \%$, and $77.7 \%$ of cases, respectively, per year of the period (Figure 1). According to Rios et al. (2005), women try to commit suicide about ten times more than men but cannot reach the same lethality, suggesting that such acts represent a request for help. 
Figure 1: Total number of notified cases of attempted suicide due to exogenous drug intoxication and stratification by sex in the period from 2013 to 2017 in the city of Birigui-SP.

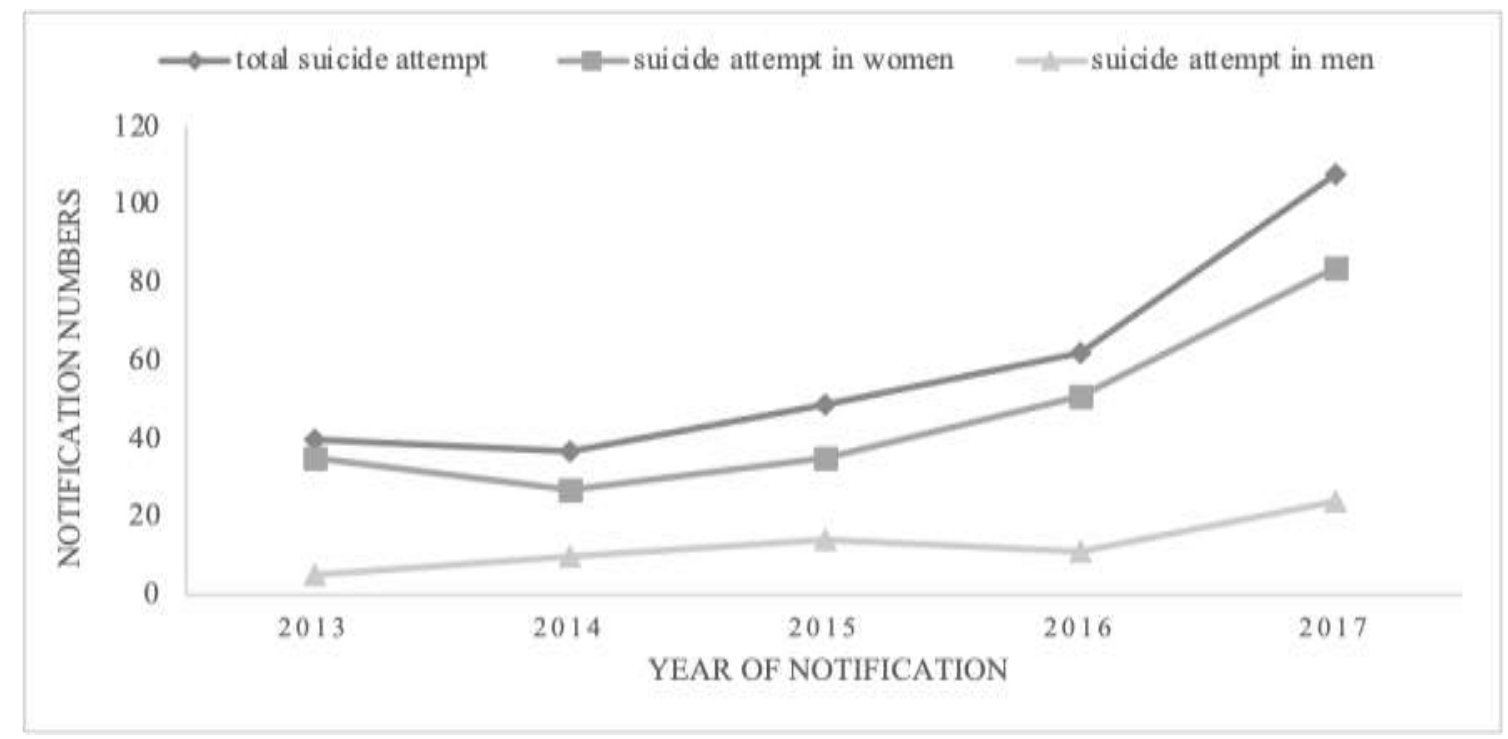

Source: Health Ministry of Brazil Informatics Department of the Unified Health System database (DATASUS)

The group of 20 to 39 years old showed the highest number of reported cases $(\mathrm{n}=150 ; 50.7 \%$ ); in the group of 40 to 59 years old there were 74 cases (25\%); from 15 to 19 years old, 49 cases $(16.7 \%)$, with the remaining age groups having a total of 23 cases $(7.8 \%)$.

According to the Brazilian Institute of Geography and Statistics (Instituto Brasileiro de Geografia e Estatística, IBGE) data, the prevalence of notifications per 1,000 in a population of 108,728 inhabitants, taking into account the number of people in each age group as in our data was5.8 cases/1,000 inhabitants 15 - 19 years old, with a population of 8,466 people; 2.6 cases/1,000 inhabitants 20 - 39 years old, with a population of 36,880 people; and 4.1/1,000 inhabitants 40 - 59 years old, with a population of 28,656 people (IBGE, 2010) (Figure 2).

Figure 2. The number of cases of attempted suicide in the period from 2013 to 2017, according to age groups adjusted per thousand inhabitants in the city of Birigui-SP.



Source: Health Ministry of Brazil Informatics Department of the Unified Health System database (DATASUS). 
These data show that the highest incidence of cases occurred in the 15 - 19 years old group, even though the total number of notifications was higher in the 20 - 39 years old group; this may be associated with what happened in Brazil between 1980 and 2010, a period in which the highest suicide rates were related to factors of low social integration as described by Silva et al. (2018). Birigui-SP, having an industrial city profile (SEADE, 2020), may reflect the behavior of low social integration especially in youngsters, who were affected by a limited opportunity to enter the labor market. Several problems have been pointed out as triggers of suicidal attempts by young individuals such as relationship problems, alcohol use, and depression (Bernardes; Turini \& Matsuo, 2010). Educational strategies can contribute to the increase of knowledge about suicide and mental health in young population (Neves; Pereira \& Pereira, 2020; Silva, et al. 2020). Besides that, the elderly population also need attention due to factors such as depression and other comorbidities present in this age group (Oliveira \& Rodrigues, 2020).

The educational level reflects the number of reported cases, that increased proportionally according to the lowest level of education throughout the evaluated period (Figure 3). Vidal et al. (2013) showed that low schooling associated with lowlevel work, qualification and residing in peripheral neighborhoods were identified as factors associated with suicidal attempts by exogenous drug intoxication.

Figure 3. Notifications of attempted suicide by exogenous drug intoxication in the period from 2013 to 2017 according to the education level in the city of Birigui-SP.



Source: Health Ministry of Brazil Informatics Department of the Unified Health System database (DATASUS).

The recurrence of purposeful exposure to toxic substances showed a predominance of acute-single involving 157 cases (53\%), followed by acute-repetition with 63 cases (23.1\%), and chronic type exposition with 7 cases (2.4\%) (Table 1). No studies have been identified that presented similar variables; however, in the study by Rodrigues et al. (2006), the recurrence rate among young people represented $30 \%$ to $40 \%$ of the cases, occurring in the first six months after the initial attempt.

The data on clinical evolution showed that 189 cases (63.9\%) were cured without sequels, 4 cases (1.4\%) were cured with sequels, and 103 cases (34.8\%) were ignored or left blank (Table 1). In 2013, 11,985 cases (28.45\%) of exogenous drug intoxications were reported to the National Toxic-Pharmacological Information System (Sistema Nacional de Informações Tóxico-Farmacológicas, SINITOX); 7,306 cases (60.96\%) evolved to cure, and 22 cases (0.18\%) presented sequelae. In 
agreement with the study of Trevisan et al. (2012), a cure without sequelae is present in most of the evolutions, and they found that drugs are the most used agents compared to other substances in suicidal attempts.

Table 1. Distribution of suicidal attempts regarding the recurrence (in $\%$ and notifications numbers [n]) of exposure to exogenous intoxications and clinical evolution over the years in the city of Birigui-SP.

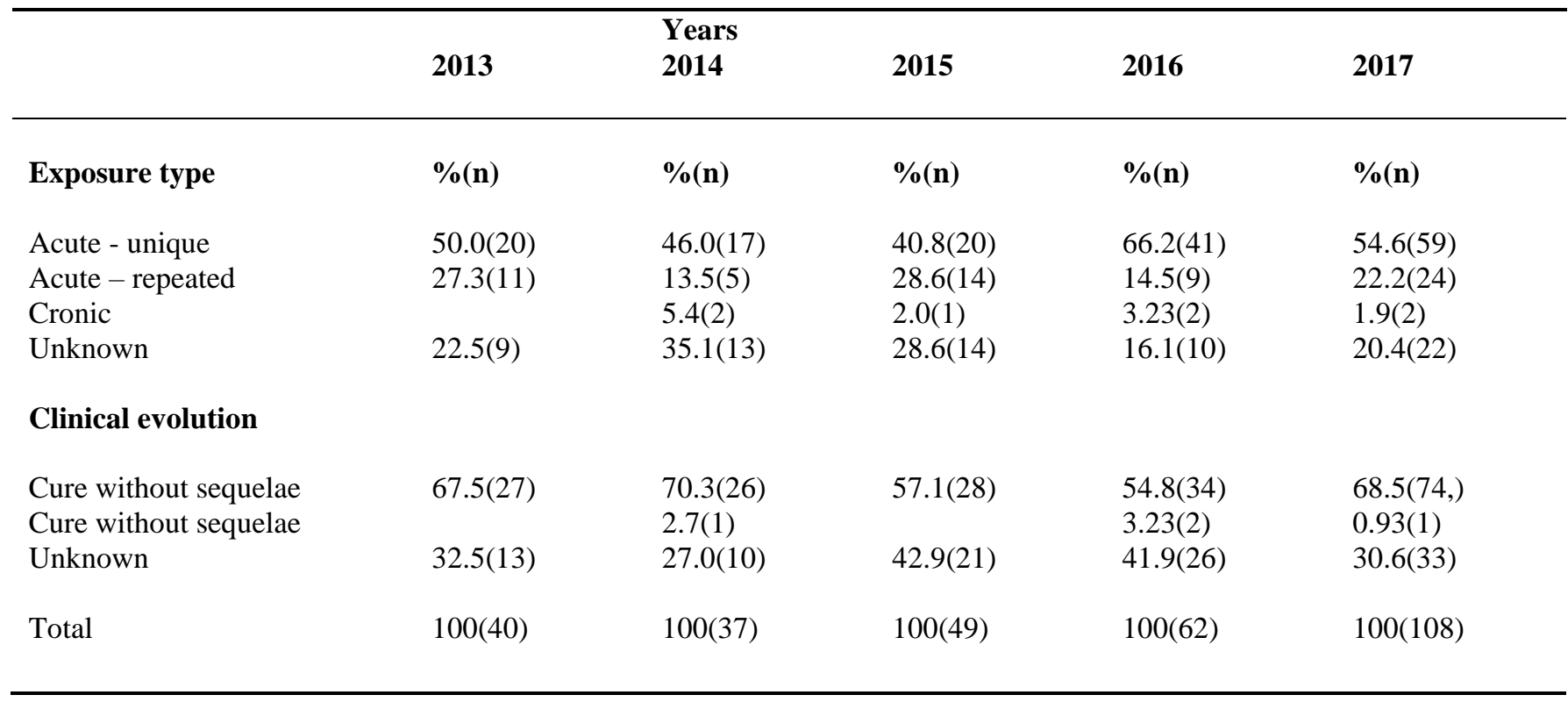

Source: Health Ministry of Brazil Informatics Department of the Unified Health System database (DATASUS).

According to the Brazilian Ministry of Health, prevention of suicide depends critical on several factors such as not treating the issue as a taboo and the awareness of health-service professionals of conditions that lead to suicidal despair. The stigmatization of suicide makes it difficult for individuals to seek help and seek solutions when health professionals are not efficiently prepared to deal with such situations (Brasil, 2018). Psychological assessment of the patient by the prescriber before prescribing psychoactive drugs and guidance for appropriate treatment can also minimize the problem (Oliveira, et al. 2020).

Other elements to be considered are the underreporting of cases and failures in communication from the public and private sectors, the effective referral to psychiatric and psychological departments, and family monitoring, the continuity of treatment, and the prevention of recurrence of the suicide attempt.

\section{Conclusion}

Exogenous drug intoxication was most prevalent in the population of Birigui-SP in suicide attempts. Victims were predominantly young women and persons of a low level of education, utilizing mainly acute, single exposure intoxication that evolved to cure without the presence of sequels. Further studies are necessary to understand better the association of exogenous intoxication and suicide in small urban centers focusing on social behavior of different aged population.

\section{References}

Bernardes, S. S., Turini, C. A., \& Matsuo, T. (2010). Perfil das tentativas de suicídio por sobredose intencional de medicamentos atendidas por um Centro de Controle de Intoxicaçõesdo Paraná, Brasil. Cadernos de Saúde Pública, 26 (7), 1366 - 1372.

Brasil. Secretaria do Estado do Mato Grosso do Sul. Ministério da Saúde divulga $1^{\circ}$ boletim de suicídio no país., é a quarta causa de morte entre jovens. (2017). https://www.saude.ms.gov.br/ministerio-da-saude-divulga-1-boletim-de-suicidio-no-pais-e-a-quarta-causa-de-morte-entre-jovens/. 
Research, Society and Development, v. 10, n. 8, e13510817152, 2021

(CC BY 4.0) | ISSN 2525-3409 | DOI: http://dx.doi.org/10.33448/rsd-v10i8.17152

Brasil. Ministério da Saúde. Ministério da Saúde atualiza dados sobre suicídio. (2018). https://portalarquivos2.saude.gov.br/images/pdf/2018/setembro/20/Coletiva-suic--dio.pdf

Brasil. Ministério da Saúde. Novos dados reforçam a importância da prevenção do suicídio. (2018). https://antigo.saude.gov.br/noticias/agencia-saude/44404novos-dados-reforcam-a-importancia-da-prevencao-do-suicidio

IBGE - Panorama populacional da cidade de Birigui - SP. 2010. https://cidades.ibge.gov.br/brasil/sp/birigui/panorama

Neves, C. C. S., Pereira, A. P. C., \& Pereira, C. A. S. (2020). Strategies of suicide prevention within the school for teenagers: a literature review on the base medline. Research, Society and Development, 9(7), e300973945.

Oliveira, E. N., Carvalho, A. G., Moreira, R. M. M., Melo, B. T., Lima, G. F., \& Ximenes Neto, F. R. G. (2020). Interfaces between abusive use of psychoactive substances, presence of comorbidities, and suicide risk. Research, Society and Development, 9(7), e262974172.

Oliveira, R. L., \& Rodrigues, R. F. de L. (2020). Suicide of the elderly: the fragilized tie with the desire of being alive. Research, Society and Development, 9(9), e406997336

OMS. Organização Mundial da Saúde. Prevenção do suicídio: um recurso para conselheiros. Genebra, 2006. http://www.who.int/mental_health/media/counsellors_portuguese.pdf.

Pereira, A. S., Shitsuka, D.M., Parreira, F. J., Shitsuka, R. et al. (2018). Metodologia da pesquisa cientifica. UFSM.

Rios, D. P. (2005). Tentativa de suicídio com o uso de medicamentos registrados pelo CIT-GO nos anos 2003 e 2004. Revista Eletrônica de Farmácia, 2 (1), 6-14.

Rodrigues, D. S., Rebouças, D. S., Teles, A. M. S., Conceição Filho, J. N., Guimarães, C. R. R., Santana, O. A. M., Tanajura, G. M., \& Rigo, S. C. C. (2009). Apostila de Toxicologia Básica: Centro de Informações Antiveneno da Bahia-CIAVE.

Rodrigues, R. S., Nogueira, A. C. F. M., Antolini, J., Berbara, V., Oliveira, C. (2006). Suicídio em jovens: fatores de risco e análise quantitativa espaçotemporal (Brasil, 1991-2001). Revista Brasileira de Medicina de Família e Comunidade, 2 (7), 177-188.

São Paulo. Fundação Sistema Estadual de Análise de Dados. Perfil dos Municípios Paulistas. (2020). https://perfil.seade.gov.br/.

Silva, B. F. A., Prates, A. A. P., Cardoso, A. A., \& Rosas, N. (2018). O suicídio no Brasil contemporâneo. Revista Sociedade e Estado, 33 (2), $565-579$.

Silva, D. A. B. da, Vieira, F. H. M., França, T., \& Pereira, S. de S. (2020). Dialogue as suicide prevention among High School adolescents. Research, Society and Development, 9(8), e144985358.

Trevisan, E. P. T., Santos, J. A. T., \& Oliveira, M. L. F. Tentativa de suicídio de mulheres: dados de um centro de assistência toxicológica do Paraná. (2013). Revista Mineira de Enfermagem, 17 (2), 412-417.

Vidal, C. E. L., Gontijo, E. C. D. M., \& Lima, L. A. (2013). Tentativas de suicídio: fatores prognósticos e estimativa do excesso de mortalidade. Cadernos de Saúde Pública, 29 (1), $175-187$.

World Health Organization. Suicide in the World (2019). https://apps.who.int/iris/bitstream/handle/10665/326948/WHO-MSD-MER-19.3-eng.pdf?u—=1 